\title{
ISOLATION OF 2 NOVEL RFLP MARKERS AND THEIR LOCALIZATION AT 2q35 BY MICRODISSECTION AND SUBSEQUENT ENZYMATIC AMPLIFICATION
}

\author{
Tetsuya Kibe, ${ }^{1, *}$ Kazuhiro Tsukamoto, ${ }^{2}$ Tetsuya Hirota, ${ }^{2}$ \\ Koh-ichiro Yoshiura, ${ }^{2}$ Tohru OHTA, ${ }^{2}$ Takaya ToHma, ${ }^{3}$ \\ Toshiya Tamura, ${ }^{4}$ Yoshihiro Jinno, ${ }^{2}$ and Norio NIIKAwA ${ }^{2}$ \\ ${ }^{1}$ Department of Pediatrics, Nagoya City University Medical School, \\ Mizuho-ku, Nagoya 467, Japan \\ ${ }^{2}$ Department of Human Genetics, Nagasaki University School of Medicine, \\ Sakamoto-machi, Nagasaki 852, Japan \\ ${ }^{3}$ Department of Pediatrics, School of Medicine, University of the Ryukyus, \\ Nishihara-Uehara, Okinawa 903-01, Japan \\ ${ }^{4}$ Department of Child Development, Kumamoto University School of Medicine, \\ Honjo, Kumamoto 860, Japan
}

\begin{abstract}
Summary We previously constructed a chromosome $2 \mathrm{q}$-specific genomic library and isolated a number of microclones. In the present study, we first analyzed with Southern hybridization whether any of the microclones represent restriction fragment length polymorphisms (RFLPs), and then tried to map RFLP markers physically, using the recently developed chromosome microdissection/enzymatic amplification method. Of 13 clones analyzed, two were RFLP markers; a clone, pM2C83, showed a fourallele MspI RFLP, and the other, pM2C8, a two-allele RsaI RFLP. In order to assign the two polymorphic markers, two chromosomal segments, $2 \mathrm{q} 32-\mathrm{q} 35$ and $2 \mathrm{q} 35$-qter, on the chromosome 2 from a karyotypically normal person were microdissected, and the DNA from each segment was amplified with the polymerase chain reaction (PCR) using marker sequence-specific primers. With this method, both of the clones were assigned to $2 \mathrm{q} 35$. These two RFLP markers must be useful for linkage analysis of genetic diseases whose loci are at around $2 \mathrm{q} 35$.
\end{abstract}

Key Words Novel RFLP markers, microdissection, polymerase chain reaction (PCR), mapping, 2q35

Received August 18, 1992; Accepted September 29, 1992.

* To whom correspondence should be addressed. 


\section{INTRODUCTION}

The chromosome microdissection technique has been developed as a convenient tool to isolate microclones from a defined chromosomal region of interest (Lüdecke et al., 1989, 1990; Senger et al., 1990; Johnson, 1990; Jinno and Niikawa, 1990; Kao and Yu, 1991; Djabali et al., 1991). We previously constructed a human chromosome $2 \mathrm{q}$-specific genomic library by means of microdissection, and isolated many single-copy DNA microclones with a size ranging 200-700 bp (Hirota et al., 1992). These microclones are available for screening of corresponding larger genomic clones and/or cDNAs from phage, cosmid or yeast artificial chromosome (YAC) libraries. In addition, the microclones may represent restriction fragment length polymorphisms (RFLPs) (Lüdecke et al., 1990; Hirota et al., 1992). However, when using them directly in linkage analysis, narrowed assignments are an $a$ priori requisite. For this purpose, chromosome fluorescence in situ hybridization (FISH) technique has generally been adopted (Hirota et al., 1992), but FISH first needs the isolation of corresponding phage or cosmid clones with a minimal size of almost $1 \mathrm{~kb}$, to be used as probes (Garson et al., 1987). An alternative mapping procedure, a chromosome microdissection and subsequent polymerase chain reaction (CM-PCR) method, has recently been developed by Han et al. (1991) and by Spielvogel et al. (1992), which involved PCR of the DNA from a defined microdissected chromosomal region using a set of clone-sequence-specific primers. This method provided rapid mapping of DNA fragments with a size as small as microclones.

The present study deals with the isolation of novel RFLP markers from the previously constructed 2q-specific microclone library (Hirota et al., 1992) and with mapping of the markers by the CM-PCR method.

\section{MATERIALS AND METHODS}

DNA microclones analyzed. We previously constructed a pUC19 2q-specific genomic library and isolated microclones from the library (Hirota et al., 1992). These microclones were used in the present study. They included pM2C1, pM2C4, pM2C7, pM2C8, pM2C9, pM2C12, pM2C28, pM2C58, pM2C63, pM2C64, $\mathrm{pM} 2 \mathrm{C} 70$, $\mathrm{pM} 2 \mathrm{C} 71$, and $\mathrm{pM} 2 \mathrm{C} 83$, and all were single-copy sequences. Although they had been confirmed to be derived from human chromosome 2 by the hybrid cell panel analysis, all but one clone (pM2C4) had not precisely been mapped. The pM2C4 already assigned to 2q33.3 (Hirota et al., 1992) was used as a positive control to evaluate the present mapping strategy.

Southern hybridization. The microclones were initially tested for RFLPs by Southern hybridization to DNAs that were isolated from six unrelated Japanese individuals and digested with each of six different restriction enzymes (MspI, TaqI, 
$R s a \mathrm{I}, B g l \mathrm{II}, P s t \mathrm{I}$, and $P v u \mathrm{II})$. The enzyme digested DNA $(6 \sim 10 \mu \mathrm{g})$ was separated by electrophoresis on $0.8 \%$ agarose gels and transferred to nylon membranes. Each microclone DNA was labeled with $\left.{ }^{[2} \mathrm{P}\right] \mathrm{dCTP}$ using the multiprime DNA labeling system (Amersham International Plc., U.K.), and used as a probe. Hybridization was performed at $65^{\circ} \mathrm{C}$ for $12-24 \mathrm{hr}$ in a mixture containing $0.125 \mathrm{M} \mathrm{Na}_{2} \mathrm{HPO}_{4}(\mathrm{pH}$ 7.2) $/ 0.25 \mathrm{M} \mathrm{NaCl} / 7 \% \mathrm{SDS} / 1 \mathrm{mM}$ EDTA/10\% PEG 6000 , and post-hybridization washing at room temperature for $15 \mathrm{~min}$ twice in $2 \times \mathrm{SSC}$ and $0.1 \% \mathrm{SDS}$, and then for $30 \mathrm{~min}$ at $65^{\circ} \mathrm{C}$ twice in $0.5 \times \mathrm{SSC}$ and $0.1 \% \mathrm{SDS}$. Hybridization signals were detected by autoradiography.

Chromosome microdissection, and PCR amplification of the chromosomal DNA. For the purpose of direct mapping of the microclones which would represent RFLPs, we adopted the CM-PCR mapping method developed by Han et al. (1991) and by Spielvogel et al. (1992). Detailed microdissection procedures themselves were the same as described previously (Jinno and Niikawa, 1990; Hirota et al., 1992; Deng et al., 1992). In short, metaphase chromosomes were freshly prepared with the short-fixation method from an EBV-transformed lymphoblastoid cell-line of a karyotypically normal male. A chromosomal region, 2q33-qter, which was corresponding to the derivation of our microclones, was divided into two parts, regions A (2q32-q35) and B (2q35-qter) (Fig. 1, A and B). Each of the regions was microdissected under an inverted microscope with a fine glass needle by handling a micromanipulator. Since these chromosomal regions could not accurately been cut-out, a small part of the dissected fragments might contain common DNAs, especially at around $2 \mathrm{q} 35$. Five chromosomal pieces from each region were collected, and incubated with a proteinase solution, containing $0.5 \mathrm{mg} / \mathrm{ml}$ proteinase $\mathrm{K} / 0.1 \% \mathrm{SDS} / 10 \mathrm{mM}$ Tris- $\mathrm{HCl}(\mathrm{pH} 7.5) / 10 \mathrm{~mm}$ sodium chloride, at $37^{\circ} \mathrm{C}$ for $4 \mathrm{hr}$. Chromosomal DNA was extracted with phenol/chloroform.

In order to design primer DNAs for the PCR amplification of the microdissected chromosomal DNA, microclones showing RFLPs and the control clone (pM2C4) were partially sequenced by the dideoxy-chain termination method (Sanger et al., 1977) using T7 DNA polymerase (Sequenase, Biochemical Corporation, Cleveland, Ohio, USA; Catalogue No. 70700). Based on their sequences, clonespecific oligonucleotide primer pairs were synthesized (Table 1). All the agents used but the template DNAs were pre-treated with psoralen-UV (Jinno et al., 1990) to avoid amplification of possible contaminated DNAs.

The DNA from each microdissected chromosomal region was transferred into $50 \mu$ of a PCR reaction mixture $(50 \mathrm{~mm} \mathrm{KCl} / 20 \mathrm{~mm}$ Tris- $\mathrm{HCl}, \mathrm{pH} 8.5 / 1.5 \mathrm{~mm} \mathrm{Mg-}$ $\mathrm{Cl}_{2} / 0.1 \%$ Tween $20 / 0.2 \mathrm{mM}$ each of $\mathrm{dNTP}$ and $100 \mathrm{ng}$ each of primers). After adding $2 \mathrm{U}$ of Taq polymerase to the mixture, the DNA was PCR-amplified in an automated temperature controller (Program Temp Control System PC-7000, ASTEC Co., Tokyo). After the first $20 \mathrm{PCR}$ cycles $\left(95^{\circ} \mathrm{C}\right.$ for $2 \mathrm{~min}, 55^{\circ} \mathrm{C}$ for $2 \mathrm{~min}$, and $72^{\circ} \mathrm{C}$ for $2 \mathrm{~min}$ ), another $1 \mathrm{U}$ of Taq polymerase was added, and additional 20 cycles were performed. At the end of the 40th cycle, $10 \mu \mathrm{l}$ reaction mixture was 


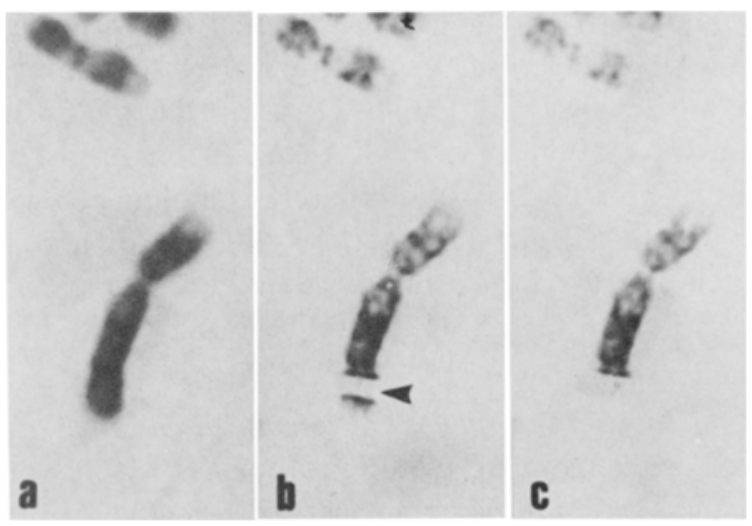

Fig. 1A. A chromosome 2 before microdissection (a), and after dissection of region A (2q32-q35) (b), and region B (2q35-qter) (c).

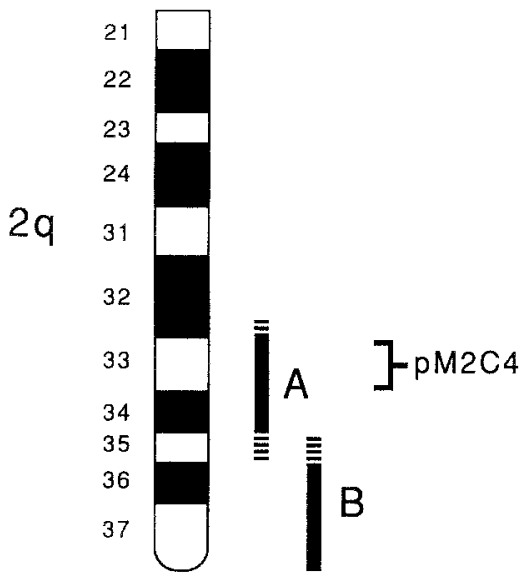

Fig. 1B. Localization of dissected regions A and B, and the pM2C4 on chromosome 2. Solid and dotted bars indicate confidently dissected regions and possible overlapping regions, respectively.

Table 1. Sequences of three primer sets used in the present study.

\begin{tabular}{|c|c|c|c|c|}
\hline $\begin{array}{l}\text { Corresponding } \\
\text { DNA to be } \\
\text { amplified }\end{array}$ & Primer & Sequence $\left(5^{t}-3^{\prime}\right)$ & $\begin{array}{l}\text { Predicted } \\
\text { size of } \\
\text { amplified } \\
\text { DNA }\end{array}$ & $\begin{array}{c}\text { Annealing } \\
\text { temperature }\end{array}$ \\
\hline pM2C83 & $\begin{array}{l}\mathrm{C} 83 \mathrm{f} \\
\mathrm{C} 83 \mathrm{r}\end{array}$ & $\begin{array}{l}\text { CAGCATTTCCTAGGAGTGAC } \\
\text { ACACTTCTGATTAGAGTCCC }\end{array}$ & $138 \mathrm{bp}$ & $55^{\circ} \mathrm{C}$ \\
\hline $\mathrm{pM} 2 \mathrm{C} 8$ & $\begin{array}{l}\mathrm{C} 8 \mathrm{f} \\
\mathrm{C} 8 \mathrm{r}\end{array}$ & $\begin{array}{l}\text { ACTCAGTCCTGCTCCAACTT } \\
\text { GCTCCAGAATGATTATCTGG }\end{array}$ & $73 \mathrm{bp}$ & $55^{\circ} \mathrm{C}$ \\
\hline $\mathrm{pM} 2 \mathrm{C} 4$ & $\begin{array}{l}\mathrm{C} 4 \mathrm{f} \\
\mathrm{C} 4 \mathrm{r}\end{array}$ & $\begin{array}{l}\text { AGGAAGCGTAGGGAGTAGAT } \\
\text { AGGATCTTGGTAAATGGTTACC }\end{array}$ & $109 \mathrm{bp}$ & $55^{\circ} \mathrm{C}$ \\
\hline
\end{tabular}


subjected to electrophoresis on a $6 \%$ polyacrylamide gel and the PCR products were visualized by ethidium bromide staining.

\section{RESULTS}

\section{Identification of RFLPS}

Of the 13 microclones analyzed with Southern hybridization, two, pM2C83 and pM2C8, represented polymorphisms. The probe pM2C83 with a size of 550 bp identified a $M s p I$ RFLP with four alleles $(6.8 \mathrm{~kb}, 6.2+0.6 \mathrm{~kb}, 4.6 \mathrm{~kb}$, and $4.0+$ $0.6 \mathrm{~kb}$ ) (Table 2 and Fig. 2a). A $0.6 \mathrm{~kb}$ fragment was observed, always accompanied with the 6.2 and the $4.0 \mathrm{~kb}$ fragments. These four alleles segregated in two families in an autosomal codominant fashion (Fig. 2a). The other probe pM2C8 with a size of $600 \mathrm{bp}$ detected an RsaI RFLP with 2 alleles, 2.9 and $1.1 \mathrm{~kb}$ (Fig. 2b). Allele frequencies at the two loci among 40 or 60 unrelated Japanese

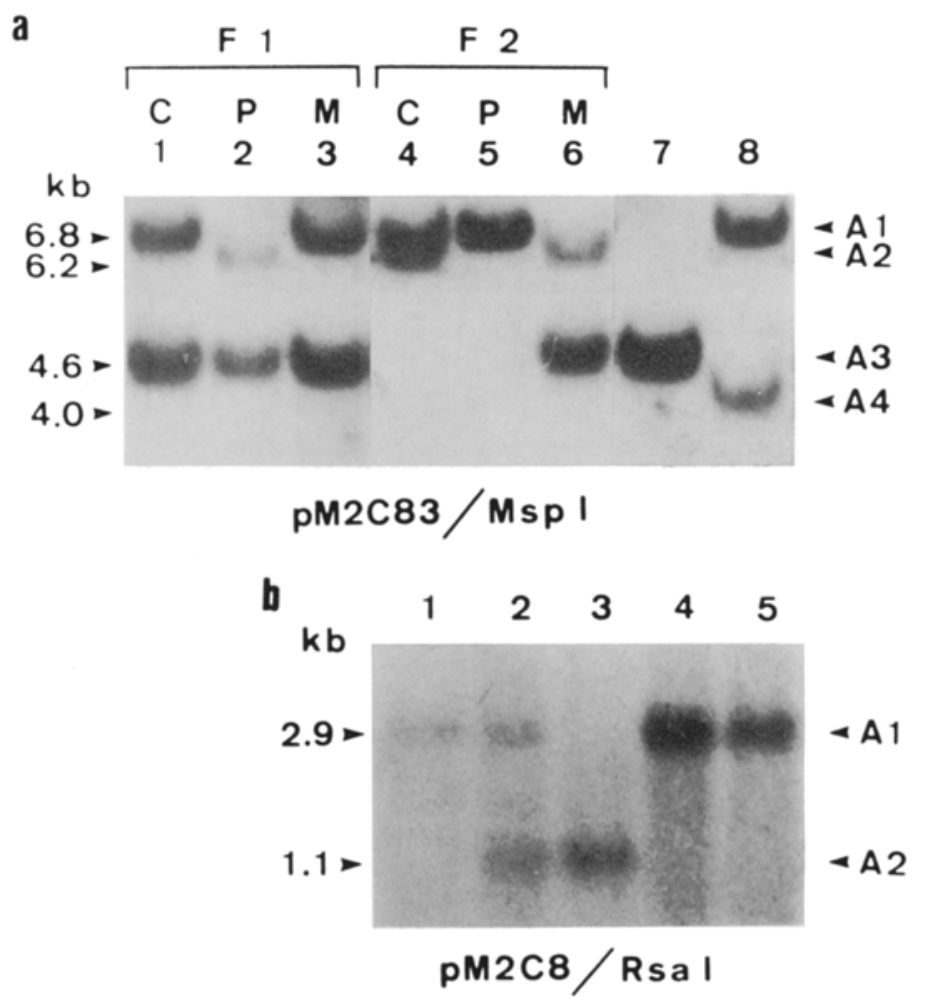

Fig. 2. RFLPs detected by two microclones, pM2C83 (a) and pM2C8 (b). a: Arrowheads on the right induicate 4 alleles which are detected in 8 individals (lanes 1-8) and transmitted from father (P) or mother (M) to a child (C) of family 1 (F1) and/or family $2(\mathrm{~F} 2)$. b: Two alleles are shown by arrowheads on the right. 
Table 2. Allele frequencies of $\mathrm{pM} 2 \mathrm{C} 83$ and $\mathrm{pM} 2 \mathrm{C} 8$ polymorphisms in the Japanese.

\begin{tabular}{|c|c|c|c|c|c|c|}
\hline \multirow{2}{*}{ Probe } & \multirow{2}{*}{ Locus } & \multirow{2}{*}{ Enzyme } & \multicolumn{3}{|c|}{ Allele } & \multirow{2}{*}{$\begin{array}{c}\text { Number } \\
\text { of } \\
\text { chromosome }\end{array}$} \\
\hline & & & Symbol & Size $(k b)$ & Frequency & \\
\hline \multirow[t]{4}{*}{ pMC83 } & $2 q 35$ & $M s p \mathrm{I}$ & $\mathrm{A} 1$ & 6.8 & 0.48 & 120 \\
\hline & & & $\mathrm{A} 2$ & $6.2+0.6$ & 0.13 & \\
\hline & & & A3 & 4.6 & 0.38 & \\
\hline & & & A4 & $4.0+0.6$ & $<0.01$ & \\
\hline \multirow[t]{2}{*}{$\mathrm{pM} 2 \mathrm{C} 8$} & $2 q 35$ & Rsal & $\mathrm{A} 1$ & 2.9 & 0.67 & 80 \\
\hline & & & $\mathrm{A} 2$ & 1.1 & 0.33 & \\
\hline
\end{tabular}

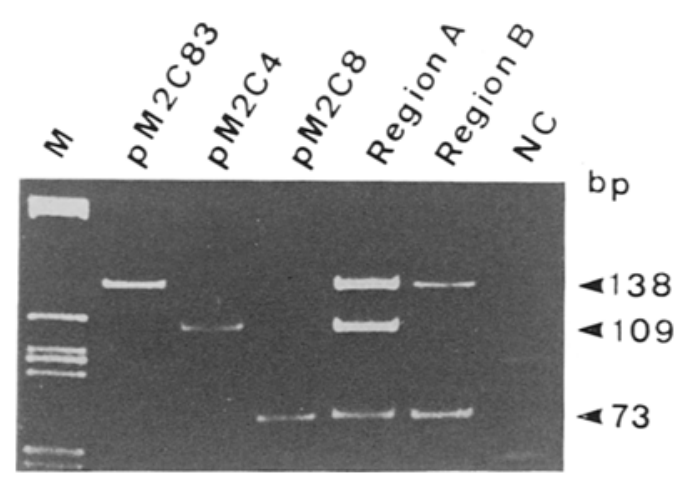

Fig. 3. Polyacrylamide gel electrophoresis of PCR products with combinations of primer sets. Lanes $\mathrm{M}$ and $\mathrm{NC}$ (b) are for size marker and negative control DNAs, respectively.

are shown in Table 2. The MspI RFLP detected by pM2C83 was much informative, showing $58 \%$ heterozygosity among 60 Japanese individuals, although the $4.0+0.6 \mathrm{~kb}$ allele was very rare. The RsaI detected by pM2C8 showed $40 \%$ heterozygosity in 40 Japanese.

\section{Mapping of polymorphic microclones}

The PCR on total human DNA using a primer pair, C83f and C83r, led to a single product with a predicted size of $138 \mathrm{bp}$ (Fig. 3). Likewise, the PCR of total human DNA with the other two sets, $\mathrm{C} 8 \mathrm{f} / \mathrm{C} 8 \mathrm{r}$ and $\mathrm{C} 4 \mathrm{f} / \mathrm{C} 4 \mathrm{r}$, amplified a predicted $73 \mathrm{bp}$ fragment and a $109 \mathrm{bp}$ fragment, each as a single band, respectively. These experiments confirmed the results of previous Southern blot analyses that all the three clones were single-copy sequences (Hirota et al., 1992), and indicated that our primer pairs could detect the corresponding sequences from total genomic DNA.

Using a mixture of the three primer sets, the PCR of the DNA from each of the dissected chromosomal regions A and B amplified both the 138 and the $73 \mathrm{bp}$ 
fragments, in addition to the $109 \mathrm{bp}$ fragment. Using the C4f/C4r set, only a 109 bp positive control fragment was amplified in the DNA from region A but not from region $\mathrm{B}$ (Fig. 3).

\section{DISCUSSION}

We isolated two novel RFLP markers, pM2C83 and pM2C8, from a 2q-specific pUC19-library which had been constructed by means of microdissection (Hirota et al., 1992). Although these microclones had a size as small as $0.6 \mathrm{~kb}$, they could directly be used as probes for the standard Southern hybridization.

Since the two markers had not accurately been assigned, we tried to map them by the CM-PCR mapping strategy, in which a $2 q 32-q 35$ region (region $A$ ) and a 2q35-qter region (region $B$ ) from a normal male were separately microdissected and the subsequent PCR was performed using clone-sequence-specific primers. When using the primer set for the control microclone (pM2C4) with known localization, only a DNA fragment with a predicted size was PCR-amplified at the predicted chromosomal region, whereas when using a mixture of three sets of primers each specific for each clone, PCR products for both pM2C83 and pM2C8 were observed at either region $\mathrm{A}$ or $\mathrm{B}$. This might indicate that the two dissected chromosomal regions overlapped each other, and that both $\mathrm{pM} 2 \mathrm{C} 83$ and $\mathrm{pM} 2 \mathrm{C} 8$ are localized at an estimated overlapping site, 2 q35.

In one of the original CM-PCR methods, Han et al. (1991) microdissected only one piece of a chromosomal segment and amplified the chromosomal DNA. To avoid possible contaminations or non-specific amplifications, they adopted the nested PCR. It has been pointed out that dissected chromosomal DNAs are often damaged during the microdissection procedures (Lüdecke et al., 1990; Senger et al., 1990; Hirota et al., 1992), leading to the PCR amplification of some curious DNAs. In the present study, a combination of an employment of the psoralenUV method, dissecting more numbers of chromosomal pieces and reduced PCR cycles could overcome these problems and provided rapid and efficient mapping of our microclones. The CM-PCR method is thus simple and highly specific, and useful for mapping of microclones. Although in general, the longer sequencing of microclones, the more appropriate primers for PCR are obtained, primers covering 200-300 bp of template DNA would actually work as shown in the present study. In addition, multiplex PCR was also available for simultaneous mapping of several DNA markers.

Each RFLP marker isolated and mapped in our study is highly informative, and may contribute to the construction of a linkage map involving a $2 q 35$ region, to which the genes for Waardenburg syndrome type $\mathrm{I}$, rhabdomyosarcoma, and for Ehlers-Danlos syndrome type X are mapped (Human Gene Mapping 11, 1991).

Acknowledgments We express our gratitude to Dr. Iwasaki, Nagasaki University, for providing genomic DNA samples of normal individuals, and Professor Yoshiro Wada, Nagoya City 
University for his valuable comments on the manuscript.

This study was supported in part by Grants-in-Aid for Scientific Research (B) (02454493), Scientific Research on Priority Areas (02262103, 03258232 and 04253233) and for Human Genome Analysis (The representative, Professor Kenichi Matsubara) from the Ministry of Education, Science and Culture of Japan.

\section{REFERENCES}

Deng H-X, Yoshiura K, Dirks RW, Harada N, Hirota T, Tsukamoto K, Jinno $Y$, Niikawa $N$ (1992): Chromosome-band-specific painting: Chromosome in situ suppression hybridization using PCR products from a microdissected chromosome band as a probe pool. Hum Genet 89: $13-17$

Diabali M, Nguyen C, Biunno I, Oostra BA, Mattei MG, Ikeda J, Jordan BR (1991): Laser microdissection of the fragile $\mathrm{X}$ region: Identification of cosmid clones and of conserved sequences in this region. Genomics 10: 1053-1060

Garson JA, van den Berghe JA, Kemshead JT (1987): Novel non isotopic in situ hybridization technique detects small $(1 \mathrm{~kb})$ unique sequences in routinely G-banded human chromosomes: Fine mapping of N-myc and b-NGF genes. Nucleic Acids Res 15: $4761-4770$

Han J, Mei LC, Brown GB, Rado TA (1991): Direct amplification of a single dissected chromosomal segment by polymerase chain reaction; A human brain sodium channel gene is on chromosome 2q22-q23. Proc Natl Acad Sci USA 88: 335-339

Hirota T, Tsukamoto K, Deng H-X, Yoshiura K, Ohta T, Tohma T, Kibe T, Harada N, Jinno $Y$, Niikawa $N(1992)$ : Microdissection of human chromosomal regions 8q23.3-q24.11 and 2q33-qter: Construction of DNA libraries and isolation of their clones. Genomics 13: 349354

Jinno Y, Niikawa N (1990): A PCR-amplification and direct cloning method for the dissected DNA from a defined chromosomal region: A microdissection-microcloning method. Exp Med (Tokyo) (in Japanese) 8: 1052-1057

Jinno Y, Yoshiura K, Niikawa N (1990): Use of psoralen as extinguisher of contaminated DNA in PCR. Nucleic Acids Res 18: 6739

Johnson DH (1990): Molecular cloning of DNA from specific chromosomal regions by microdissection and sequence-independent amplification of DNA. Genomics 6: 243-251

Kao FT, Yu JW (1991): Chromosome microdissection and cloning in human genome and genetic disease analysis. Proc Natl Acad Sci USA 88: 1844-1848

Lüdecke H-J, Senger G, Claussen U, Horsthemke B (1989): Cloning defined regions of the human genome by mircodissection of banded chromosomes and enzymatic amplification. Nature 338: $348-350$

Lüdecke H-J, Senger G, Claussen U, Horsthemke B (1990): Construction and characterization of band-specific DNA libraries. Hum Genet 84: 512-516

Sanger F, Nicklen S, Coulson AR (1977): DNA sequencing with chain-terminating inhibitors. Proc Natl Acad Sci USA 74: 5463

Senger G. Lüdecke H-J, Horsthemke B, Claussen U (1990): Microdissection of banded human chromosomes. Hum Genet 84: 507-511

Spielvogel H, Hennies H-C, Claussen U, Washington SS, Chakravarti A, Reis A (1992): Bandspecific localization of the microsatellite at D13S71 by microdissection and enzymatic amplification. Am J Hum Genet 50: 1031-1037

Human Gene Mapping 11, London Conference (1991): Eleventh International Workshop on Human Gene Mapping. Cytogenet Cell Genet $58(\mathbf{1 - 4})$ 